Max-Planck-Institut für demografische Forschung Max Planck Institute for Demographic Research Konrad-Zuse-Strasse 1 - D-18057 Rostock - GERMANY

Tel +49 (0) 3812081 - 0; Fax +49 (0) 3812081 - 202;

http://www.demogr.mpg.de

MPIDR WORKING PAPER WP 2004-018

JUNE 2004

\title{
The Demographics of Same-Sex „Marriages" in Norway and Sweden
}

\author{
Gunnar Andersson (andersson@ demogr.mpg.de) \\ Turid Noack (turid.noack@ssb.no) \\ Ane Seierstad (ane.seierstad@ssb.no) \\ Harald Weedon-Fekjær (harald.fekjar@basalmed.uio.no)
}

This working paper has been approved for release by: Andres Vikat (vikat@demogr.mpg.de)

Deputy Head of the Laboratory of Contemporary European Fertility and Family Dynamics.

(C) Copyright is held by the authors.

Working papers of the Max Planck Institute for Demographic Research receive only limited review. Views or opinions expressed in working papers are attributable to the authors and do not necessarily reflect those of the Institute. 


\title{
The Demographics of Same-Sex ,Marriages“ in Norway and Sweden
}

\author{
by Gunnar Andersson ${ }^{1}$, Turid Noack ${ }^{2}$, Ane Seierstad ${ }^{2}$, and Harald Weedon-Fekjær ${ }^{3}$
}

May 21, 2004

\begin{abstract}
:
The present study provides an investigation of the demographics of same-sex marriages, or registered partnerships ("registrerade partnerskap"), in Norway and Sweden. We give an overview of the demographic characteristics of such spouses, and study patterns in divorce risks. A comparison with similar dynamics of heterosexual marriages is provided. Our study is based on longitudinal information from the population registers of the two countries covering all persons in partnerships. Our demographic analyses involve information on characteristics such as age, sex, geographical background, experience of previous opposite-sex marriage, biological parenthood, and educational attainment of the partners involved. We find that in many respects the distributions of married populations over these characteristics differ by the sex composition of couples. Patterns in divorce risks are quite similar in same-sex and opposite-sex marriages, but divorce-risk levels are considerably higher in samesex partnerships. The divorce risk in female partnerships is practically double that of the risk in partnerships of men.
\end{abstract}

${ }^{1}$ Max Planck Institute for Demographic Research, Konrad-Zuse-Str. 1, 18057 Rostock, Germany. E-mail: andersson@demogr.mpg.de

2 Statistics Norway, POB 8131 Dep, 0033 Oslo, Norway.

E-mail: turid.noack@ssb.no and ane.seierstad@ssb.no

3 Section of Medical Statistics, University of Oslo, Norway.

E-mail: harald.fekjar@basalmed.uio.no 


\section{Registered partnerships: A new family type}

At present, the issue of granting legal recognition to same-sex couples is high on the political agenda in a large number of countries. In places where such a family type is not recognized, the debate tends to be intensifying. In many countries in Europe, it is already well established, and the discussion then more often concerns various amendments to existing rules. The first country at all to introduce a legal recognition of same-sex unions was Denmark in 1989, and the term "registered partnership" was invented for that purpose. In all Nordic countries, same-sex couples today have the possibility to contract a registered partnership, a civil status that in practice is not much short of a marriage. Such a family type was in the second place introduced in Norway in 1993, subsequently in Sweden in 1995, Iceland in 1996, and, finally, in Finland in 2002. By 2003, same-sex unions had been given legal recognition in one form or another also in Germany, France, Hungary, Portugal, Belgium, and the Netherlands ${ }^{1}$. In 2001, the latter country became the first in the world to amend its marriage act to give couples of the same sex admission to marry in the same manner as opposite-sex couples.

In terms of innovation in family-demographic behavior, the Scandinavian countries are often singled out as forerunners, which other countries subsequently tend to follow in behavior. It might be debatable whether this really is true in a more general sense, but in the case of same-sex partnerships this certainly seems to be a correct description. Consequently, it might be worthwhile to have a closer look at the Nordic experience of same-sex family life. Several studies deal with the various political and legal aspects of the introduction of same-sex partnerships in Europe ${ }^{2}$. There is, however, still sparse knowledge about the demographic behavior that is related to this new family type. The purpose of our study is to provide some knowledge of that kind.

Our study provides an overview of demographic characteristics and patterns in divorce risks of couples in registered partnerships in Norway and Sweden. The

1 In some further countries, like the USA, Canada, and Spain, same-sex unions had sometimes been legalised at the level of states and regions.

2 For a discussion of the passage of the partnership legislation in Denmark, see Søland (1998). Nielsen (1990) provides further evidence of legal aspects of the new family type. Noack (2000) discusses the introduction of registered partnerships in Norway, and Agell (1998) refers to the debate about the introduction of partnerships in Sweden. Martin and Théry (2001) discuss the introduction of another related family form, PACS, in France, which is open for same-sex and opposite-sex couples alike. For an overview of how the way to same-sex marriage got paved in the Netherlands, see Waaldijk (2001). 
analysis is based on information from Norwegian and Swedish population registers. For our purpose, we have managed to link information on various demographic and socioeconomic characteristics of the same individuals from different other administrative registers. The study is an extension of previous work based on Norwegian data, where we, for example, found that the majority of partnerships were male and that the fraction of cross-national partnerships was fairly high (Noack 2000). A first analysis of divorce risk in same-sex partnerships showed that in Norway, lesbian couples had a considerable higher divorce risk than male couples. Another group with a high propensity to divorce were cross-cultural couples, i.e., couples in which one of the two partners was non-Nordic (Noack, Fekjær and Seierstad 2002). In the present study, we provide an elaborate comparison including similar data on partnerships in neighboring Sweden. In addition, we incorporate data on divorce risks of heterosexual married people. Such a thorough comparison of divorce risk patterns in opposite and same-sex marriages has thus far never been performed. The reason is, of course, that the legalization of same-sex partnerships is a recent development, and that the time available for observation has been brief. In our study, we thus manage to compare patterns and demographic behavior of a clearly defined total population of "married" same-sex couples to an equally defined population of opposite-sex couples.

\section{Family dynamics of gays and lesbians: Previous research}

During the last decades family patterns of many countries have become more diverse. Although small in numbers and far from being accepted in most countries, legalization of same-sex marriages fits neatly into this development. The increasing diversity is often regarded as a part of a larger cultural change, implying an increase in freedom as well as an obligation for individuals to decide how to organize their lives in an individualized society (Beck and Beck-Gernsheim 1995).

Another factor that might have paved the way for same-sex marriages is the increasing separation between reproduction and sexuality, in favor of a more plastic sexuality in the terminology of Giddens (1992). Sexuality has naturally always been separated from reproduction in homosexual relations, and this separation is becoming increasingly dominant also in heterosexual relationships. Thus, the disparity between homo- and heterosexual relationships is being diminished. The increasing acceptance 
and legal legitimacy of homosexual practice may be the most important change regarding sexuality in the last decades, or as Giddens (1992:33) expressed it “... sexual diversity, although still regarded by many hostile groups as perversion, has moved out of Freud's case-history notebooks into the everyday social world".

Moxness (1993), a Norwegian sociologist, has argued that same-sex marriages have become legalized not so much because homosexuality has become more accepted, but because marriage has become an increasingly empty institution and no longer is seen as a mandatory entrance to adult life, sexual life, and parenthood.

New patterns of family life calls for new topics of research, and recent years have witnessed an increase in research on lesbian and gay lifestyles, and on same-sex families. Although the literature about same-sex relationships is abundant, most of it does not allow for the deduction of any firm demographic hypotheses. Many studies are based on small number of individuals. They have given interesting but often anecdotal information. Large-scale quantitative studies are rare. Many studies face serious problems related to sampling or representativity. In recent years, however, there has been an increasing recognition of the need to deal with these problems. As a result, more solid demographic studies have indeed appeared (Black et al. 2000).

\section{2a. General problems in studying gays and lesbians}

Lack of representative samples is the most fundamental problem in quantitative studies on gays and lesbians. Self-recruited samples from an unknown population have been and still are very common in studies of homosexuals. Respondents are, for example, recruited by snowball methods, from the readers of particular magazines, from members of organizations for gays and lesbians, or more recently using those who are willing to fill in questionnaires presented at the Internet. Critical voices have also pointed out that much of the research on family life of gays and lesbians is done by studying white, welleducated, American middle-class people (Patterson 2000).

In addition to such sampling problems, the question of how to identify homosexual people is increasingly debated. Should respondents be asked to self-identify themselves, or is it better to measure sexual practice, i.e., to ask about number of lifetime same-sex partners, any such partner within a certain time period, the sex of the majority of partners, and so on? (Black et al. 2000). According to large-scale population studies carried out in the US, the proportion of men having had a male sex partner in a 
last previous year is about 1-3 percent, as compared to 4-9 percent having had at least one male partner in the life time (Spira et al. 1993; Lauman et al. 1994; Black et al. 2000). The proportions of women having had a partner of the same sex are somewhat lower, well over 1 percent and about 4 percent, respectively. A different pattern is reported from a Norwegian study. In this survey, the proportions of respondents aged 1926 were slightly higher for women than for men when it concerns same-sex experience during the last 12 months as well as during life time (Pedersen and Kristiansen 2003:11). All the estimates referred to above are well below the often mentioned 10 percent benchmark of the famous report of Alfred C. Kinsey. This estimate however seems to be a misinterpretation of what Kinsey in fact had said (Sandfort et al. 2000). Kinsey's study was based on information about life-time homosexual activity as well as homosexual desire, resulting in different levels of estimates. Notwithstanding, Kinsey's sampling procedure also had its weaknesses.

Not only the methodology, but also the view that individuals may be divided into gays, lesbians, bisexuals, and heterosexuals has met increasing criticism. The possibility that sexual identities may shift over time has attracted increasing attention (Patterson 2000). So far, little research may document such contentions. A recently published study of younger Norwegians finds, however, some signs of a confluent sexual culture, and more so among women than among men (Pedersen and Kristiansen 2003).

To give a statistical portrait of any gay and lesbian population using traditional population surveys has also been considered difficult because of the mere size of the target groups. Or put another way, in standard demographic data sources, it may seem like looking for the needle in the haystack. In addition, the underlying assumption of most demographic surveys is heterosexual, and respondents often have no possibility to report on other types of family behavior than those suggested by the survey designers (Hoem et al. 2000: 87). The seemingly sensitive character of the topic has probably also made it difficult to include it in questionnaires where it otherwise might had appeared natural. Nevertheless, a number of existing data sources today allow for research on same-sex couples as defined by any co-residence of two persons of the same sex.

\section{2b. Same-sex couples and same-sex co-residence}

For the United States, Black et al. (2000) have made a critical review and comparison of three sources available for systematic studies of the gay and lesbian populations: The 
General Social Survey, the National Health and Social Life Survey, and the 1990 U.S. Census. Although documenting a number of measurement-error problems in the surveys and a considerable underreporting of same-sex couples in the census they conclude that the data sets seem good enough to allow for credible analyses of gays and lesbians in the US. Based on these data, they compare partnered gays and lesbians with the general population. They find that lesbians as well as gays have attained more education than married and non-married heterosexual partnered women and men. Partnered gays earn, however, less than men living in opposite-sex marriages. For women, the opposite is the case, partnered lesbians earn more than married women. These results appear when the comparisons are made between persons within similar age and educational categories. They conform to a related study by Black et al. (2001) that also included non-partnered individuals. A related study for the Netherlands, however, shows only negligible effects of sexual orientation on earnings (Plug and Berkhout 2004). For further research on the economic lives of lesbians and gay men see Badgett (1997, 2001).

In addition, the US Census data indicates that 5 percent of male couples and nearly 22 percent of female couples live with children in the household. Although adoption and artificial insemination for lesbians and gays frequently are reported in the media, Black et al. (2000) conclude that most of the children of partnered gays and lesbians recorded in the census probably have been born while the parents lived in a previous opposite-sex marriage. 20 percent of partnered gays and 30 percent of partnered lesbians were previously married. The data also gives information on patterns in geographical settlement. Gay men seem to be concentrated to a selected number of urban areas, preferably big cities. Lesbian women are less concentrated, and more often live in smaller metropolitan areas. For a further discussion on why patterns in geographical concentration of gay men arise, see Black et al. (2002).

Conventional demographic data have also been used to study the matching behavior of same-sex couples. Based on the US 1990 Census, Jepsen and Jepsen (2002) find positive assortative mating for four types of couples: married and cohabiting opposite-sex couples and male and female same-sex couples. Same-sex couples appeared more alike in their labor-market characteristics than did opposite-sex couples, while the opposite was the case for various non-labor-market traits.

Evidently, census data that include information on household characteristics of surveyed individuals allow for the study of co-residing couples of the same sex. However, such data are not non-problematic; same-sex co-residential individuals have 
not to be synonymous with gay and lesbian couples ${ }^{3}$ (Voon Chin Phua and Kaufman 1999). Such problems with ambiguity of data also appear when heterosexual cohabitation is studied. Co-residing persons of the opposite sex does not necessarily have to be sexual partners (Baughman et al. 2002).

\section{2c. Family dynamics in same-sex marriages as compared to opposite-sex marriages}

A main purpose of our study is to provide information on the family dynamics in samesex marriages as it can be measured in the manner of partnership-dissolution risks. In this respect we have not much of previous research to rely on. An overview of recent research on the family relationships of gays and lesbians by Patterson (2000) gives moderate information on the stability of gay and lesbian relationships. The study of duration of relationships typically requires a panel design or highly reliable retrospective data. So far, such data have been hard to establish for an appropriate study of couple dynamics of gays and lesbians ${ }^{4}$. Patterson (2000) concludes, however, that it seems reasonable to believe that some of the problems in homosexual relationships will stem from the same roots as problems experienced by opposite-sex couples. By contrast, the literature on divorce of heterosexual married couples is abundant. Considering the impact of various demographic variables, studies of such couples indicate that pairing at a very young age, low socio-economic status, low education, a considerable age difference between the spouses as well as socio-cultural differences are important risk factors for divorce (Clarke and Berrington 1999; Sayer and Bianchi 2000). For some of these factors, however, like that of a high risk for spouses with little formal education and for those in manual-worker occupation, the elevated divorce risk might decrease with the duration of marriage (Jalovaara 2002).

\footnotetext{
3 A recent German large-scale data source that includes information on same-sex and opposite-sex couples alike seems to be more precise in these aspects. The German Mikrozenus includes information on co-residence and also asks respondents to specify if they consider themselves living in a "Gleichgeschlechtliche Lebensgemeinschaft" (same-sex union) or any other type of family. Such selfidentified same-sex couples are much fewer than the total of co-residing same-sex couples. Eggen (2002) suspects that problems connected with self-identification results in underreporting, and assumes that any "true" level of same-sex cohabitation in Germany would lie somewhere in between the numbers arising from the two possible definitions.
}

4 Kurdeck $(1992,1995)$ provides a study on the stability of gay and lesbian couples in the US. However it is based on such tiny data that it hardly offers any possibility to make generalizations to a wider population of gays and lesbians. 


\section{Data and methods}

The object of our study is registered partnerships in Norway and Sweden. Such a civilstatus type has nearly the same legal consequences as a marriage. This means that registered partners have the same rights and duties as married heterosexual couples in relation to each other and to society. The acts are basically the same in all Nordic countries, but differ in the opportunity to adopt children, to have artificial insemination and to solemnize the partnership 5 . This being said, the legal rights and duties connected to marriage are less critical in Scandinavia than in other countries. (For an overview on family law and the consequences of marriage in countries in Europe, see Hamilton and Perry, 2002). In the context of the Nordic welfare state, social rights are largely based on individuals, regardless of their family status. Economic motives that may be important for marriage in the US, like those of the possibility of a common healthinsurance coverage, are virtually non-existent in the universalistic welfare state.

The data for our calculations on partnership dynamics are derived from the population-register systems of Norway and Sweden, which with a high degree of accuracy cover the populations of the two countries and their recordable vital events. Each change in civil status is recorded in the registers, and since each individual living in one of the two countries has a unique personal identity code we have been able to derive longitudinal histories of the family dynamics of each person who has ever registered a partnership formation in any of the two countries. Similar event histories can be collected for individuals who have married heterosexually, and we have managed to include such data for Sweden ${ }^{6}$. This allows for a proper comparison of our populations of same-sex partnerships with that of an equally defined population of opposite-sex marriages. The populations are defined by their civil status; there is no ambiguity in the categories we use. Individuals who have never lived in any of the two countries cannot be traced directly in the registers and some partnerships that

\footnotetext{
5 Churches are not available for ceremonies of partnership formation. In Norway the actual registration is performed by a Notarius Publicus, in Sweden by a court or a private person with special authorization. Medical assisted insemination is not given to women living in registered partnership either in Norway or Sweden. From 2003 registered partners in Sweden got the admission to jointly adopt children, including all types of international adoption. In Norway only admission to adopt the other partner's child is given (Waaldijk 2003).
} 
involve persons living abroad cannot be incorporated properly into our analyses. In the case of Sweden, we had to exclude 100 same-sex couples from our analyses since we had no information at all on one of the two partners involved.

The first part of our analysis is descriptive, where we display various demographic characteristics of individuals who have formed a partnership in Norway or Sweden. These characteristics are derived from various administrative registers and are measured at the time of partnership formation. We have defined our variables so that they give the characteristics at the couple level. Our demographic description involve information on characteristics such as age, sex, geographical background, experience of previous opposite-sex marriage, biological parenthood, and educational attainment of the partners involved. Our variables are defined as follows.

We depict the age composition of persons registering a partnership by giving the mean age of the two partners at the time of registration. The distribution is given over the categories "mean age 30 or less", "mean age 31-40", and "mean age 41 or above". In addition, we give the distribution over various categories of the age difference between the two partners involved.

For both countries, we describe what fraction of partnerships that involve at least one person living in the capital area at the time of partnership formation 7 . For Norway, this is the City of Oslo, while for Sweden, we use the greater Stockholm metropolitan area as our geographical demarcation. We further describe the geographical background of the partners by giving the distribution over various national origins. We distinguish between couples where both partners are locals, and couples where at least one of the partners comes from abroad. In Norway, national origin is measured by citizenship at the time of partnership formation. In Sweden, it is instead measured by country of birth. We report on couples where at least one partner comes from another Nordic country, another European country (including the overseas Anglo-Saxon countries), a non-European country, or where the national

6 The data cover marriages contracted in 1993-1999, Swedish partnerships contracted in 1995-2002, and Norwegian partnerships contracted in 1993-2001. The minor discrepancy in the observation period of marriages as compared to that of registered partnerships in Sweden is due to data availability.

${ }^{7}$ Most partners are likely to live together at the time of partnership formation, but need not necessarily be registered (yet) as living at the same address. In our data for Sweden, we found that about half of the partners involved had been registered as living together at the same address already for a period of at least two years prior to their partnership registration. 
origin is not known. If both partners are foreigners and from different categories of countries, they are designed to the most "distant" category of our country scale.

We further describe the partners by their various previous experience of registered heterosexual family life. We give the percentage of unions where at least one of the two partners previously has been heterosexually married, and where at least one of the two is a parent. In the case of parenthood and previous marriage, we have to be aware that these figures only cover events that are registered in the local country. We have no information about possible previous marriages of immigrants contracted abroad or children to immigrants that have never lived in Sweden or Norway, as the case may be.

Finally, we provide a description of the educational characteristics of the partners. We report on the highest educational level at the time of partnership formation, as summarized at the couple level. In addition, we can provide information on the various fields of education that the partners had at that time. The data on educational orientation contain nine categories, and we provide them as summaries over individuals rather than over couples.

When examining patterns in divorce, we use the fixed characteristics described above as determinants of divorce. In addition, we add one further covariate in order to account for if a couple belonged to the pioneers of same-sex marriages of the first twelve months it was possible to register a partnership in the country considered. A relatively large number of partnerships were contracted in the first year and we might suspect that these pioneers differ somewhat in their behavior from those who registered in subsequent years.

Our study amounts to a longitudinal event-history analysis of divorce risks. We calculate relative risks of divorce by the various categories of our variables at hand. We follow each couple from the month of partnership formation to any registration of divorce or to censoring due to the death of one of the partners, emigration of both partners, or the end of the last year for which we have data, whichever comes first. The registration of partnership dissolution follows the same legal procedures as those of marriage dissolution in Norway and Sweden. The procedures differ between the two countries, however, which affects the timing of the registration of divorce. In Norway, partners and spouses have to register as being legally separated during a period of one year before being granted a divorce. In Sweden, there is no such prerequisite, but if one of the partners disagrees to the 
divorce he or she might ask for a six-month waiting period before the divorce is legalized and registered ${ }^{8}$.

Technically, we estimate proportional-hazards (intensity-regression) models of the divorce process. Such models are a standard tool for the analysis of timedependent data like ours. In the Swedish analyses, we have incorporated the basic time variable "duration of partnership" as a piece-wise constant covariate. In the Norwegian case, we have estimated models that are based on a non-parametric time factor. These differences in modeling are due to differences in the softwares we have used: S-PLUS in the case of Norway, RocaNova in the case of the Swedish analyses. They have no impact on the relative risks that we present.

With data on couples in different types of unions, we are able to compare the characteristics and patterns of behavior in male partnerships with those in female partnerships. Similarly, we can compare patterns in unions in Norway with those in Sweden, and, finally, patterns in same-sex marriages with those in opposite-sex partnerships.

\section{The populations of registered partners in Norway and Sweden}

Our first observation is that the incidence of same-sex marriage in Norway and Sweden is not particularly impressive in terms of numbers. Our data for Norway consist of 1,293 partnerships contracted in 1993-20019. During the same calendar period, 190,000 heterosexual marriages were contracted, which gives a ratio of around 7 new same-sex marriages to every 1000 new opposite-sex marriages. For Sweden our data comprise 1,526 partnerships contracted in 1995-2002 ${ }^{9}$. Related to the corresponding 280,000 heterosexual marriages registered during the same calendar

8 These legal differences in the timing of divorce in Norway and Sweden could have caused problems if we were about to estimate joint divorce models based on the combined data of the two countries. However in our case, we aimed at estimating separate models for Norway and Sweden, and have no problems in identifying the accurate divorce-risk patterns of each country considered.

9 The number of partnerships included in our study is slightly larger than that found in official statistics on partnership formation in Norway and Sweden. The reason for such a discrepancy is that official statistics only report events of individuals living in the country (at the time of partnership formation). Norwegian statistics report new partnerships if the oldest partner lived in Norway, while Swedish statistics are entirely based on individuals and thus report new registered partners living in Sweden. In our research, we have managed to retrieve information also on partners who subsequently moved to the country of partnership registration. 
period, we get a ratio of 5 new partnerships to every 1000 new opposite-sex marriages. The ratios of partnerships to marriages are thus considerably lower than the various estimates of fractions of homosexuals that we referred to in Section 2. The incidence of partnership formation in the two countries also appears relatively low when compared to levels of partnership formation in Denmark and the Netherlands (Waaldijk 2001: 463; Noack et al. 2002: Figure 1; Eggen 2002: 229; Festy et al. 2004).

Trends in partnership formation by country and sex (Figure 1) reveal that the developments in annual numbers of new partnerships have been quite similar in the two countries. Both countries exhibited a particularly high level of partnership formation immediately after the law on registered partnerships came into force. In both countries the number of partnerships of men has been about 60 percent higher than that of women: 62 percent of all partnerships have been male. The initial spurt in partnership formation was followed by a few years of stable trends at a lower level, and a subsequent increase in registration during the most recent years. The recent increase has been stronger for women than for men so that the sex gap in partnership formation has narrowed.

Table 1 gives a more detailed description of the composition of partnerships. It also provides a comparison with couples of newly contracted opposite-sex marriages in Sweden. It shows that new same-sex partners on the average are considerably older than corresponding opposite-sex spouses ${ }^{10}$. About one third of all partnerships were contracted by partners at ages 41 and above. In Sweden, half of all new male partnerships involved partners with a couple mean age above 40. By contrast, only 14 percent of heterosexual marriages involved such senior spouses. The relatively high ages also allow for a larger age gap between same-sex partners. Substantial age differences between partners are more common in same-sex partnerships than in opposite-sex marriages. They are more common in partnerships of men than in partnerships of women: Around one third of all male partnerships are formed by partners where the age difference amounts to ten years or more.

In both countries, same-sex couples tend to be concentrated to the metropolitan areas: Oslo and Stockholm. This tendency is stronger in Norway than in

\footnotetext{
10 The mean age of newly married heterosexual spouses was close to 30 years while the mean age of all newly registered homosexual partners was close to 40 years.
} 
Sweden, and in both countries it is stronger for men than for women. In Norway, 62 percent of male partnerships and 45 percent of female partnerships involved a partner living in the city of Oslo. Only 11 percent of the total Norwegian population live in Oslo. In Sweden, 47 percent of male new partnerships and 36 percent of female partnerships involved a partner living in the Stockholm region, as compared to 21 percent of registered heterosexual marriages.

Same-sex partnerships also differ from opposite-sex marriages in that they more often involve a foreign-born partner. This is particularly the case for partnerships of men. In Norway, 43 percent of male partnerships involve a nonNorwegian citizen. In Sweden, 45 percent of the gay partnerships involve at least one foreign-born partner. In the latter country, 22 percent of newly contracted heterosexual marriages also involve at least one partner of foreign origin. This figure does not necessarily suggest that Swedes tend to marry foreigners: The 22 percent correspond rather well with the total share of foreign-born people living in Sweden at the ages when people marry.

It is not uncommon that partners in same-sex unions have the experience of previous heterosexual family life. In our summary, we find that a fourth of lesbian partnerships involve at least one partner who has been previously married to a man. This fraction happens to be exactly the same as that of newly contracted heterosexual marriages: one fourth of such unions involve at least one previously married spouse. Evidently, lesbian women are somewhat older at partnership formation and have had more time for previous marital life than their heterosexual counterparts. The corresponding numbers for male partnerships are somewhat lower.

The experience of previous heterosexual marital life corresponds quite well to the fractions of partnerships that involve a partner who is a parent. Parenthood is more common in female partnerships than in male unions. It is more common in partnerships in Sweden than in Norway. One third of lesbian partnerships in Sweden involve a least one parent. In the same country, 58 percent of all newly contracted heterosexual marriages also involved parents. In Scandinavia it is more common to marry after entry to parenthood than before having a first child, if at all.

When it comes to socio-economic characteristics, we find that same-sex partners have a relatively high educational attainment. Between 56 and 67 percent of homosexual partnerships involve at least one partner with a tertiary education. The corresponding fraction for new heterosexual marriages is 44 percent. The difference 
had been even larger if we would have accounted for the fact that the educational attainment typically is higher for persons of younger cohorts and that same-sex partners more often than others belong to somewhat older cohorts.

We conclude our description by providing an overview of the educational orientation of individuals in our study populations (Table 2). Since the educational registers of Sweden and Norway contain information also on the type of education a person has attained we are in a position to examine to what extent we can find any systematic differences in characteristics also along that dimension of individual educational capital. A comparison of the groups of married women reveals that the differences are not that dramatic, but that lesbian women to a larger extent than other women have an education with an aesthetic orientation. Married gay men have a similarly high, by around 10 percent, fraction of individuals with an aesthetic education, and do otherwise not differ very much from the populations of married women as it concerns their field of education. They differ from heterosexual married men in having a much lower fraction of individuals with a technically oriented education. Heterosexual married men instead have a very low fraction of individuals with an education oriented towards health care.

\section{Patterns of divorce in same-sex "marriages" in Norway and Sweden}

In Table 3, we display the relative risks of divorce of couples in registered partnerships for each sex and country separately. As a comparison, we provide the corresponding risks for heterosexual marriages in Sweden. They are calculated for each of the variables described above, except for that of educational orientation. They give the effects of any level of a certain covariate relative to a baseline category of the same covariate. A risk of say 1.20 indicates that the risk of divorce is 20 percent higher for couples of the relevant category than for couples belonging to the reference category of the same variable. The risks are derived from a multivariate model, which means that the effects of any variable hold when we control, or standardize (Hoem 1993), for the simultaneous effects of the other variables included in the model.

The general impression of the results of our calculation is that patterns in divorce in partnerships and in marriages are remarkably similar when it comes to the 
effects of the covariates. The results can be summarized as follows ${ }^{11}$. We find no systematic or important difference in divorce propensities between the pioneering partners of the first year of partnership registration and subsequently registered partners. For both heterosexual spouses and registered partners, we find a clear age gradient in divorce risks in that persons who contract a marriage or register a partnership at young ages have much higher divorce risks than persons who do this at more mature ages. In most cases, we find that a relatively large age difference between the two partners is related to an elevated propensity for divorce. Divorce risks do not differ very much between couples of the capital region and couples registered elsewhere in the two countries. In contrast, the stability of unions is negatively affected by the involvement of at least one foreign partner. The destabilizing effect of any previous experience of a heterosexual marriage is not at all as apparent for same-sex couples as it is for heterosexually married couples. The effect of premarital parenthood seems to differ somewhat between male and female couples, but patterns appear quite irregular and should not be given too much attention. When it concerns a couple's educational characteristics, we mainly find that a high educational attainment is related to lower divorce risks. For Sweden, we find a very clear gradient in the effects of partners' educational level. For Norway, it is more irregular. Finally, we find that the profile of divorce risks by time since marriage formation is practically the same for same-sex partnerships and opposite-sex marriages.

In the next step of our analysis, we examine to what extent the propensity to divorce differs by the sex of the partnership, and if it differs between registered partnerships and opposite-sex marriages. This is done by means of estimating common models for partnerships of women and men, and in the case of Sweden, for partnerships and marriages. A covariate for type of union gives information on divorce risks by the different family types. Table 4 contains the relative risks for Norway and Table 5 contains those of Sweden. For Norway, an introductory model

11 A statistical testing reveals that not all variables appear significant at a 5-percent level. For Sweden, it is only "age", "educational level", and "duration of partnership" that turns out to have significant effects. For Norway, only "age" turns out to be significant in all models. In the case of heterosexual marriages, however, each single effect is significant at the 5-percent level. Note that most of the risk patterns we observe are very stable across the various sub-populations of married people. Regardless of significance, such a stability in patterns reassures us that we in general can trust our findings, but that we should not take every single deviation in divorce risk as an established fact. 
that only includes type of union as a covariate (Raw model) first indicates that divorce risks are 77 percent higher in lesbian partnerships than in those of gay men. To some extent, this could have been the result of various differences in the composition of gay and lesbian partnerships over different demographic characteristics. However, a model that controls for the effect of such covariates (Extended model) instead reveals that the excess risk of divorce in female partnerships actually is more than twice that of the risk in male unions.

For Sweden, we find the same relation between the divorce risks of lesbian and gay partnerships. In addition, we provide a comparison with the divorce-risk level of opposite-sex marriages (Table 5). An introductory model without further explanatory variables (Raw model) shows that the divorce risk in partnerships of men appears 50 percent higher than the corresponding risk in heterosexual marriages, and that the divorce risk in partnerships of women is about the double of that of men. Again, such differences in risk levels could partly be the result of differences in the composition of the different groups we study. We know, for example, that same-sex partnerships relatively often involve a non-native partner and that such characteristics are related to higher divorce risk. On the other hand, registered same-sex partners are often older than corresponding opposite-sex spouses, which is a feature that is related to a lower propensity for divorce. It turns out that a control for the demographic characteristics at hand ${ }^{12}$ (Extended model) does not alter the basic relation we found between divorce risks in different types of families.

One basic difference between same-sex partnerships and opposite-sex marriages is that most often the former family type does not produce children. It could therefore be the case that the relatively lower divorce risk of heterosexual marriages to some extent is related to their parenting. In order to examine such a hypothesis we have estimated two additional models that are based on childless couples only. We have thus excluded all partnerships and marriages where at least one of the two partners was a parent at the time of registration. In addition, we have censored each childless heterosexual marriage at the time of any first birth. A crude model without further demographic covariates (Raw model C) indicates that the excess risk of

\footnotetext{
12 In such a common model of registered partnerships and heterosexual marriages we exclude variables for partnership cohort, previous marriage, and parenthood. The meaning of these variables differ between the populations and the relative risks of Table 3 show that the effects on divorce differ as well.
} 
divorce of gay partnerships tends to disappear when the comparison is based on childless couples. Nevertheless, an appropriate control for relevant covariates (Extended model C) leaves patterns more or less as we first found them. Such a result does not preclude that there anyway is an effect of parenthood in reducing the divorce risks in heterosexual marriages. To some extent, the disruption risks of childless heterosexual spouses might be reduced in anticipation of childbearing, i.e., when spouses stay together in order to fulfill their plans of parenthood.

\section{Reflections: The demographics of same-sex "marriages" in Norway and Sweden}

In our study, we have provided an overview of the demographic characteristics and patterns in union dynamics of the first cohorts of registered partnerships in Norway and Sweden. The data on these pioneering cohorts of same-sex spouses provide information on a family type that at present is introduced in a wider circle of countries. Since this still is a recent family type, we are in no position to say much about any long-term patterns or developments. However, our cross-country comparison still allows us to draw at least some conclusions about the dynamics of registered partnerships.

One finding is that a majority of registered partnerships were formed by male partners. To some extent, such a relation could reflect a larger fraction of gays than of lesbians in the total population. Most studies indicate that this indeed is the case. However, we know nothing about differences in the motivation for partnership registration between women and men so we cannot readily translate it into an explanation to our finding. To some extent, however, it could reflect the relative importance of some instrumental motives that appear to be relevant for partnership registration. Two such motives are more often likely to be relevant for groups of gay men than for others. The first is the need for legal protection of common assets in the face of anticipated mortality of one of the two partners ${ }^{13}$. The second is related to the migration of a foreign partner. Our data show that a very large fraction of partnerships

\footnotetext{
13 Such a motive for partnership registration could also affect the structure of the divorce risks we estimate. However, an evaluation of patterns in mortality in the different study populations reassures us that differences in mortality are unlikely to affect divorce risks.
} 
of men involve a foreign partner. In many such cases, a migration to Norway or Sweden and, consequently, coresidence might simply not be possible without the legal intervention of a partnership registration.

In many aspects, the different populations of partners and spouses differ in terms of their various demographic and socioeconomic characteristics. One interesting contrast appears in terms of educational achievement: Registered same-sex partners have achieved a considerably higher level of such individual investment than have opposite-sex partners who marry. This might suggest that a high level of certain types of human capital often is needed in order to manifest a minority family status of the kind we study. It is interesting that such an effect appears so prominently even in an equality-oriented society like the Scandinavian one.

Our population of same-sex couples is defined by their change in civil status to that of a registered partnership. Such an unambiguously defined population of gay and lesbian couples has never been studied before. Nevertheless, we find that many of the various demographic characteristics of our Scandinavian couples resemble those found for other populations of same-sex couples, such as co-residing people of the same sex in the US (Black et al. 2000). Evidently, some aspects of gay and lesbian life styles seem to be of such a common nature that they appear regardless of the type of data at hand.

Finally, we provided a divorce-risk study. We found that divorce risks are higher in same-sex partnerships than in opposite-sex marriages, and that unions of lesbians are considerably less stable, or more dynamic, than unions of gay men. In Norway as well as in Sweden, the divorce risk in female partnerships is practically double that of the risk in partnerships of men. Our data is based on legal unions of short durations only, so we can say nothing about the fraction of unions that eventually will end in disruption. Nevertheless, a higher propensity for divorce in same-sex couples may not be too surprising given this group's relative noninvolvement in joint parenthood and its lower exposure to normative pressure about the necessity of life-long unions. The difference in divorce behavior between women and men appears somewhat more puzzling. It cannot be explained by differences in the composition of couples over our explanatory factors at hand. Nevertheless, some of these differences give us some hints about possible unobservable characteristics that might be at play as well. We find that partnerships of women to a much larger extent are demographically homogamous than are partnerships of men: Lesbian 
partners often have relatively similar characteristics while gay spouses more often differ in terms of characteristics such as age, nationality, education, and income ${ }^{14}$. Such similarity in characteristics might also reflect a deeper feeling of sameness in lesbian couples. Such a sameness and a corresponding lack of clear power structures may be inducive to a high level of dynamism in the relationship, but perhaps not to the kind of inertia that is related to marital stability. Differences in divorce risks might also appear from differences in the motives of lesbians and gays for entering a registered partnership in the first hand. With our type of data, we are in no position to explore qualitative aspects of that kind, but have to leave such topics of research to colleagues in other scientific disciplines.

\section{Acknowledgements}

This paper is a joint work of the four co-authors. Our project was initiated by Turid Noack. Gunnar Andersson has contributed with the Swedish part of our study while Turid Noack, Ane Seierstad, and Harald Weedon-Fekjær have contributed with the Norwegian analyses. We are grateful to Karin Wahlbin of Statistics Sweden for preparation of the individual-partnership data of Sweden. In addition, we are grateful for comments received from Lee Badgett, Patrick Festy, Gerda Neyer, and Jens Rydström.

\footnotetext{
14 For Sweden, we have also had access to data on the income of the partners. They reveal that on the average, the distribution of income between partners in gay couples is about as unequal as that of heterosexual spouses, while lesbian partners much more often earn similarly.
} 


\section{References}

Agell, A., 1998. Alternative legal policies: A comparative view from a Swedish observer. Pp. 31-38 in Vaskovics, L., and Schattovits, H. (eds), Living Arrangements and Family Structures - Facts and Norms. Vienna: Austrian Institute for Family Studies.

Badgett, L., 1997. Beyond biased samples: Challenging the myths on the economic status of lesbians and gay men. Pp. 65-71 in: Gluckman, A., and Reed, B. (eds), Homo Economics: Capitalism, Community, and Lesbian and Gay Life. New York: Routledge.

Badgett, L., 2001. Money, Myths, and Change. The Economic Lives of Lesbians and Gay Men. Chicago: University of Chicago Press.

Baughman, R., Dickert-Conlin, S., and Houser, S., 2002. How well can we track cohabitation using the SIPP? A consideration of direct and indirect measures. Demography 39: 455-465.

Beck, U., and Beck-Gernsheim, E., 1995. The Normal Chaos of Love. Cambridge: Polity Press.

Black, D., Gates, G., Sanders, S., and Taylor, L., 2000. Demographics of the gay and lesbian population in the United States: Evidence from available systematic data sources. Demography 37: 139-154.

Black, D., Gates, G., Sanders, S., and Taylor, L., 2002. Why do gay men live in San Francisco? Journal of Urban Economics 51: 54-76.

Black, D., Makar, S., Sanders, S., and Taylor, L., 2001. The effects of sexual orientation on earnings. Syracuse University Economics Department Working Paper 2001-4.

Clarke, L., and Berrington, A., 1999. Socio-demographic predictors of divorce. Paper 1 in: Simons (ed.), High Divorce Rates: The State of the Evidence on Reasons and Remedies. London: Lord Chancellor's Department.

Eggen, B., 2002. Gleichgeschlechtliche Lebensgemeinschaften: Erste Ergebnisse einer Untersuchung im Rahmen des Mikrozensus. Pp. 215-234 in: Schneider, N., and Matthias-Bleck, H. (eds), Elternschaft Heute. Opladen: Leske+Budrich . 
Festy, P., Digoix, M., and Waaldijk, K., 2004. Same sex partnership and the Northern Europe pattern of family formation. Paper presented at the PAA 2004 Annual Meeting, Boston, April 1-3, 2004.

Giddens, A., 1992. The Transformation of Intimacy. Oxford: Polity Press.

Hamilton, C., and Perry, A., 2002. Family law in Europe. Butterworths LexisNexis.

Hoem, J.M., 1993. Classical demographic methods of analysis and modern eventhistory techniques. IUSSP: 22nd International Population Conference, Montreal, Canada, Volume 3: 281-291.

Hoem, J.M., Aassve, A., Andersson, G., Baizán, P., Billari, F., Engelhardt, H., Fürnkrantz-Prskawetz, A., Hank, K., Huinink, J., Kohler, H-P., Kohlmann, A., Kreyenfeld, M., Neyer, G., and Vikat, A., 2000. Concepts for a second round of Fertility and Family Surveys in Europe with particular attention paid to persons of reproductive/working age. In: United Nations Economic Commission for Europe/United Nations Population Fund (eds), Generations and Gender Programme: Exploring Future Research and Data Collection Options. Geneva: United Nations.

Jalovaara, M., 2002. Socioeconomic differentials in divorce risk by duration of marriage. Demographic Research 7(16). Available online www.demographicresearch.org.

Jepsen, L., and Jepsen, C., 2002. An empirical analysis of the matching patterns of same-sex and opposite-sex couples. Demography 39: 435-453.

Kurdeck, L., 1992. Relationship stability and relationship satisfaction in cohabiting gay and lesbian couples: A prospective longitudinal test of the contextual and interdependence models. Journal of Social and Personal Relationships 9: 125142.

Kurdeck, L., 1995. Lesbian and gay couples. Pp. 243-261 in D'Augelli, A., and Patterson, C., (eds), Lesbian, Gay and Bisexual Identities over the Lifespan: Psychological Perspectives. New York: Oxford University Press.

Lauman, E., Gagnon, J., Michael, R., and Michaels, S., 1994. The Social Organization of Sexuality: Sexual Practice in the United States. Chicago: University of Chicago Press.

Martin, C., and Théry, I., 2001. The PACS and marriage and cohabitation in France. International Journal of Law, Policy and the Family 15: 135-158. 
Moxness, K., 1993. Partnerskapsloven - et uttrykk for parforholdets endrede karakter. Løvetann 3: 30-31.

Nielsen, L., 1990. Family rights and the 'registered partnership' in Denmark. International Journal of Law, Policy and the Family 4: 297-307.

Noack, T., 2000. Registrerte partnerskap: 1993-1998. Samfunnsspeilet, No. 3/2000: 24-29.

Noack, T., Fekjær, H., and Seierstad, A., 2002. Skilsmisser blant lesbiske og homofile partnere - hvem er mest stabile? Samfunnsspeilet, No. 3/2002: 19-27.

Patterson, C., 2000. Family relationships of lesbians and gay men. Journal of Marriage and the Family 62: 1052-1069.

Pedersen, W., and Kristiansen, H.W., 2003. Å gjøre det, å føle det og å være det. Homoseksualitet i det senmoderne. Tidsskrift for samfunnsforskning 44: 3-37.

Plug, E., and Berkhout, P., 2004. Effects of sexual preferences on earnings in the Netherlands. Journal of Population Economics 17: 117-131.

Sandfort, T., et al., 2000. Lesbian and Gay Studies. An Introductory, Interdisciplinary Approach. London: Sage Publications.

Sayer, L., and Bianchi, S., 2000. Women's economic independence and the probability of divorce: A review and reexamination. Journal of Family Issues 21: $906-943$.

Spira, A., Leridon, H., and Gray, R., 1993. Biomedical and Demographic Determinants of Reproduction. Oxford: Clarendon.

Søland, B., 1998. A queer nation? The passage of the gay and lesbian partnership legislation in Denmark, 1989. Social Politics, Spring 1998: 48-69.

Voon Chin Phua, and Kaufman, G., 1999. Using the census to profile same-sex cohabitation: A research note. Population Research and Policy Review 18: 373-386.

Waaldijk, K., 2001. Small change: How the road to same-sex marriage got paved in The Netherlands. Pp. 437-464 in Wintemute, R., and Andenæs, M. (eds), Legal Recognition of Same-Sex Partnerships: A Study of National, European and International Law. Oxford: Hart Publishing.

Waaldijk, K., 2003. Major legal consequences and procedures of civil marriage, registered partnership and informal cohabitation for different-sex and same-sex partners in nine European countries. Work in progress, version 17 September 2003. Leiden: E.M. Meijers Institute of Legal Studies, Universiteit Leiden. 
Figure 1: Partnerships contracted in Norway and Sweden, 1993-2002

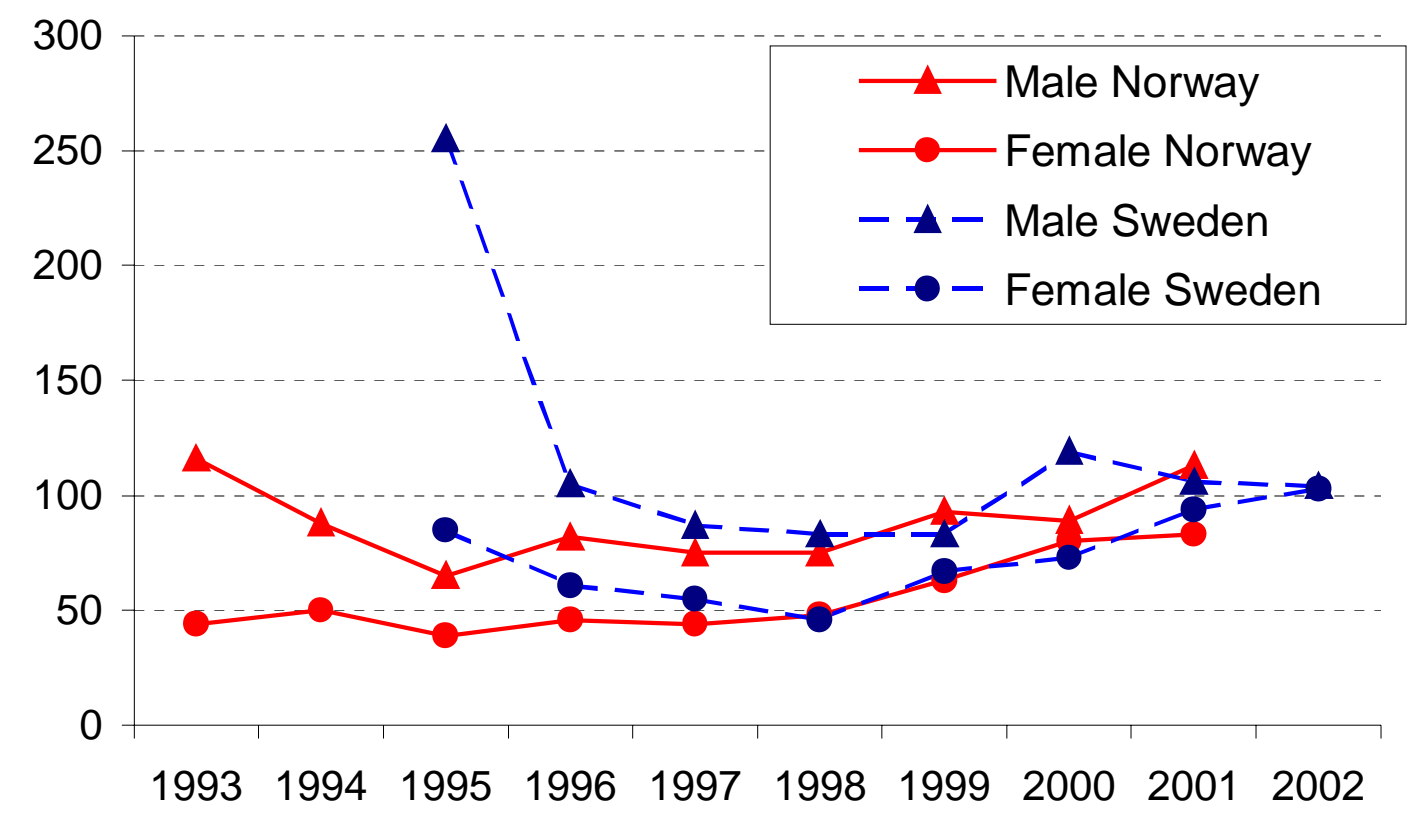


Table 1: Characteristics of partnerships contracted in Norway (1993-2001) and Sweden (1995-2002) and of marriages contracted in Sweden in 1993-1999

\begin{tabular}{|c|c|c|c|c|c|}
\hline & $\begin{array}{l}\text { Norway } \\
\text { Male }\end{array}$ & $\underline{\text { Female }}$ & $\begin{array}{l}\text { Sweden } \\
\text { Male }\end{array}$ & $\underline{\text { Female }}$ & Opposite- \\
\hline $\mathrm{N}=$ & 796 & 497 & 942 & 584 & 222000 \\
\hline Mean age of couple & $\%$ & $\%$ & $\%$ & $\%$ & $\%$ \\
\hline$<31$ & 21 & 21 & 12 & 24 & 52 \\
\hline $31-40$ & 46 & 49 & 38 & 47 & 34 \\
\hline $\begin{array}{l}41+ \\
\text { Age difference }\end{array}$ & 32 & 29 & 50 & 29 & 14 \\
\hline$<3$ & 24 & 38 & 24 & 38 & 50 \\
\hline $3-5$ & 23 & 28 & 21 & 24 & 27 \\
\hline $6-9$ & 18 & 21 & 22 & 22 & 14 \\
\hline $\begin{array}{l}10+ \\
\text { Region }\end{array}$ & 35 & 13 & 34 & 15 & 9 \\
\hline $\begin{array}{l}\text { Oslo C/Stockholm } \\
\text { Nationality/origin }\end{array}$ & 62 & 45 & 47 & 36 & 21 \\
\hline Both native & 57 & 81 & 55 & 70 & 78 \\
\hline One Nordic & 5 & 6 & 11 & 11 & 5 \\
\hline One "European" & 15 & 7 & 14 & 10 & 6 \\
\hline One non-European & 19 & 3 & 21 & 9 & 7 \\
\hline $\begin{array}{l}\text { One unknown } \\
\text { Previous heterosexual } \\
\text { marriage }\end{array}$ & 4 & 2 & -- & -- & 4 \\
\hline $\begin{array}{l}\text { At least one of partners } \\
\text { Parent(s) at registration }\end{array}$ & 15 & 26 & 20 & 27 & 27 \\
\hline $\begin{array}{l}\text { At least one of partners } \\
\text { Educational level }\end{array}$ & 13 & 24 & 19 & 34 & 58 \\
\hline Both tertiary & 19 & 34 & 20 & 32 & 17 \\
\hline One tertiary & 37 & 33 & 36 & 25 & 27 \\
\hline Both secondary & 16 & 20 & 14 & 19 & 29 \\
\hline One secondary & 22 & 11 & 20 & 16 & 19 \\
\hline Both primary/unknown & 6 & 1 & 9 & 8 & 8 \\
\hline
\end{tabular}

Source: population-register data of Statistics Norway and Statistics Sweden, authors' own computations 
Table 2: Educational orientation of women and men in Sweden who registered a partnership in 1995-2002 or married heterosexually in 1993-1999, and of women and men in Norway who registered a partnership in 1993-2001 (percent)

Sweden:

women

men

Ed. orientation

General

Aesthetic

Teaching

Administrative

Technical

Health care

Agriculture

Service

Unknown

\begin{tabular}{rrrr} 
reg. partners & married & reg. partners & married \\
\cline { 2 - 3 } 22 & 24 & 20 & 20 \\
12 & 3 & 9 & 2 \\
6 & 8 & 5 & 2 \\
17 & 25 & 20 & 15 \\
9 & 7 & 8 & 40 \\
19 & 21 & 16 & 3 \\
1 & 1 & 1 & 2 \\
6 & 6 & 6 & 5 \\
8 & 6 & 16 & 9 \\
\hline 100 & 100 & 100 & 100
\end{tabular}

Norway:

registered partners

Ed. orientation

General

Aesthetic

Teaching

women men

Administrative

14

15

Technical

$13 \quad 10$

Health care

115

\begin{tabular}{rr}
21 & 17 \\
8 & 10 \\
15 & 8 \\
2 & 3 \\
2 & 2 \\
12 & 30 \\
\hline 100 & 100
\end{tabular}

Agriculture

8

15

10

Service

Unknown 
Table 3: Relative risk of divorce in registered partnerships in Norway and Sweden, by various demographic covariates, with a comparison to divorce risks in marriages contracted in Sweden in 1993-1999

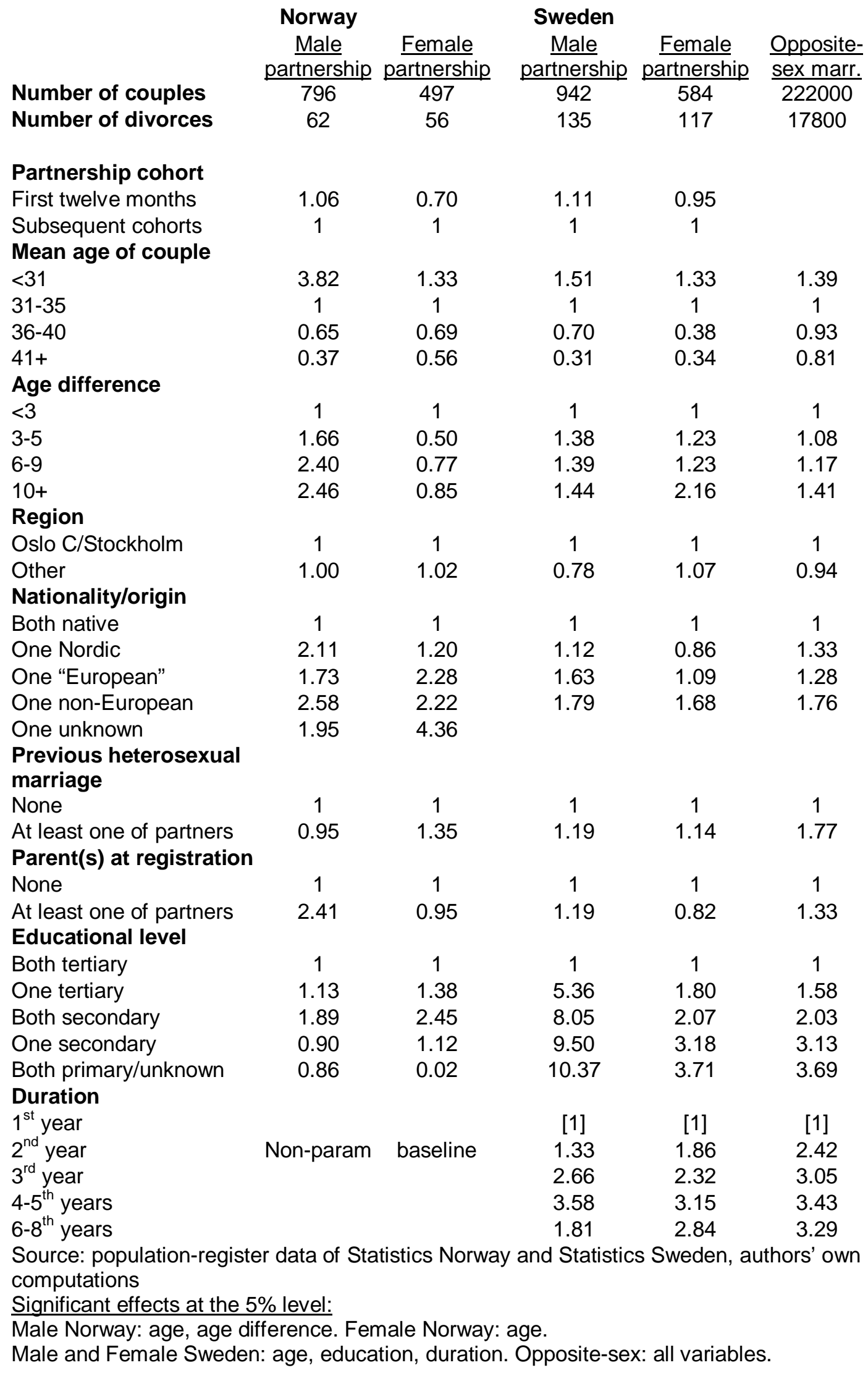


Table 4: Relative risk of divorce in registered partnerships in Norway, by sex

Type of union

Male partnership

Female partnership

Partnership cohort

First twelve months

Subsequent cohorts

Mean age of couple

$<31$

31-35

$36-40$

$41+$

Age difference

$<3$

3-5

6-9

$10+$

Region

Oslo

Other

\section{Citizenship}

Both Norwegian

One Nordic

One "European"

One non-European

Unknown

Previous heterosexual

marriage

None

At least one of partners

Parent(s) at

registration

None

At least one of partners

Educational level

Both tertiary

One tertiary

Both secondary

One secondary

Both primary/unknown

\section{Raw model Extended}

$\begin{array}{cc}1 & 1 \\ 1.77 & 2.32 \\ & \\ & 0.84 \\ & 1 \\ & 2.37 \\ & 1 \\ & 0.64 \\ & 0.45 \\ & 1 \\ & 0.84 \\ & 1.36 \\ & 1.43 \\ & 1 \\ & 0.95\end{array}$

1

1.64

2.20

3.04

3.56

1

1.10

1.00

1.57

$$
1
$$

1.12

1.90

0.93

0.70

Duration Non-param baseline

Source: population-register data of Statistics Norway, authors' own computations Significant effects at the $5 \%$ level: sex of partnership, age, citizenship, parenthood 
Table 5: Relative risk of divorce in registered partnerships and marriages in Sweden, by type of union

\begin{tabular}{|c|c|c|c|c|}
\hline \multirow[t]{2}{*}{$J_{1}+2-5$} & \multicolumn{2}{|c|}{ All couples } & \multicolumn{2}{|c|}{ Childless couples } \\
\hline & Raw model & Extended & Raw model C & Extended C \\
\hline \multicolumn{5}{|l|}{ Type of union } \\
\hline Male partnership & 1.50 & 1.35 & 1.04 & 1.49 \\
\hline Female partnership & 2.67 & 3.03 & 1.96 & 3.00 \\
\hline Heterosexual marriage & 1 & 1 & 1 & 1 \\
\hline \multicolumn{5}{|l|}{ Mean age of couple } \\
\hline$<31$ & & 1.15 & & 1.31 \\
\hline $31-35$ & & 1 & & 1 \\
\hline $36-40$ & & 1.08 & & 0.69 \\
\hline $41+$ & & 1.03 & & 0.43 \\
\hline \multicolumn{5}{|l|}{ Age difference } \\
\hline$<3$ & & 1 & & 1 \\
\hline $3-5$ & & 1.11 & & 1.10 \\
\hline $6-9$ & & 1.23 & & 1.16 \\
\hline $10+$ & & 1.50 & & 1.48 \\
\hline \multicolumn{5}{|l|}{ Region } \\
\hline Stockholm & & 1 & & 1 \\
\hline Other & & 0.95 & & 0.85 \\
\hline \multicolumn{5}{|l|}{ Country of birth } \\
\hline Both Swedish-born & & 1 & & 1 \\
\hline One Nordic & & 1.35 & & 1.01 \\
\hline One "European" & & 1.24 & & 1.21 \\
\hline One non-European & & 1.96 & & 1.71 \\
\hline \multicolumn{5}{|l|}{ Educational level } \\
\hline Both tertiary & & 1 & & 1 \\
\hline One tertiary & & 1.70 & & 1.36 \\
\hline Both secondary & & 2.27 & & 1.61 \\
\hline One secondary & & 3.71 & & 2.31 \\
\hline Both primary/unknown & & 4.46 & & 3.01 \\
\hline \multicolumn{5}{|l|}{ Duration } \\
\hline $1^{\text {st }}$ year & [1] & [1] & [1] & [1] \\
\hline $2^{\text {nd }}$ year & 2.40 & 2.40 & 2.62 & 2.59 \\
\hline $3^{\text {rd }}$ year & 3.02 & 3.04 & 3.82 & 3.78 \\
\hline $4-5^{\text {th }}$ years & 3.32 & 3.40 & 4.91 & 4.94 \\
\hline $6-8^{\text {th }}$ years & 3.07 & 3.21 & 4.00 & 4.25 \\
\hline
\end{tabular}

Source: population-register data of Statistics Sweden, authors' own computations All variables are significant at the $5 \%$ level 